\title{
Equity and Hierarchy: Reflections on the Harris
}

\section{Execution}

\author{
Steven G. Calabresi ${ }^{\dagger}$ and Gary Lawson ${ }^{\dagger \dagger}$
}

The legal controversy surrounding the execution of Robert Alton Harris is only one in a series of cases over the past few months testing the proper relationship between the Supreme Court and the inferior federal courts. Controversy over inferior federal court grants or denials of injunctions concerning Haitian refugees ${ }^{1}$ and the French abortion pill ${ }^{2}$ have starkly raised, as does the Harris case ${ }^{3}$, profound questions concerning Supreme Court review of inferior court rulings on issues involving equitable relief.

The Harris case did not display the American legal system at its finest. None of the participants in the process distinguished themselves-not the inferior courts, the Supreme Court, or Harris' counsel. Judge Reinhardt ${ }^{4}$ and Professors Caminker and Chemerinsky ${ }^{5}$ deserve credit for pointing out many of the problems posed by the Harris decisions.

$\dagger$ Assistant Professor, Northwestern University School of Law. I am grateful to the Cranston and Catherine M. Spray Fund and the Elyce H. Zenoff Fund for support.

If Associate Professor, Northwestem University School of Law. I am grateful to the Stanford Clinton, Sr. Faculty Fund for support. We are grateful to Martin H. Redish and Thomas W. Merrill for countless helpful comments and suggestions. We are also deeply grateful to Akhil Reed Amar, Guido Calabresi, Anthony D'Amato, Mayer G. Freed, Julia Harrison, Jane E. Larson, Lee S. Liberman, Lawrence C. Marshall, and Daniel Polsby for valuable comments and to Elizabeth $\mathrm{M}$. Georges for research assistance.

1. In Haitian Ctrs. Council v. McNary, No. 92-6144, 1992 U.S. App. LEXIS 17372 (2d Cir. July 29, 1992), the Second Circuit preliminarily enjoined the Coast Guard from intercepting and returning Haitian refugees fleeing to the United States. On August 1, 1992, the Supreme Court, over the dissent of Justices Blackmun and Justice Stevens, issued a stay of this order pending filing of a petition for certiorari. See McNary v. Haitian Ctrs. Council, No. A-82, 1992 U.S. LEXIS 4766 (Aug. 1, 1992). This followed a prior stay by the Supreme Court on April 22, 1992, of an injunction granted by the district court in the same case. See McNary v. Haitian Ctrs. Council, 112 S. Ct. 1714 (1992) (No. 1). Justices Blackmun and Stevens dissented from this action as well, and Justices O'Connor and Souter dissented in part. On January 31, 1992, the Supreme Court stayed another district court order in a different case raising similar issues, with Justices Blackmun, Stevens, and Thomas dissenting. See Baker v. Haitian Refugee Ctr., 112 S. Ct. 1072 (1992) (No. 1).

2. In Benten v. Kessler, 112 S. Ct. 2929 (1992), the Court refused to vacate the Second Circuit's stay of an injunction granted by the district court ordering the Food and Drug Administration to return to Benten a dosage of RU-486, the so-called French abortion pill, that she had brought into the country. Justices Blackmun and Stevens voted to vacate the stay. Id. at 2930.

3. Even though Harris' name does not appear in the captions of the relevant decisions, we refer generically to these proceedings as the Harris case. (1992).

4. Stephen Reinhardt, The Supreme Court, the Death Penalty, and the Harris Case, 102 YALE L.J. 205

5. Evan Caminker \& Erwin Chemerinsky, The Lawless Execution of Robert Alton Harris, 102 YALE L.J. 225 (1992). 
Matters were not, however, as unremittingly grim as these commentators suggest. In particular, the Supreme Court's performance, though lacking in important respects, deserves a more refined evaluation than Judge Reinhardt and Professors Caminker and Chemerinsky provide. The Court made some mistakes, but its reasoning was generally sound and its final result was correct. The Court properly held that the inexcusable lateness of Harris' fourth postconviction federal filing, combined with a measured regard for structural values of federalism and the nature of the federal judicial hierarchy, rendered an injunction against Harris' execution an abuse of discretion. Significantly, this holding, unlike the decision of the Ninth Circuit panel in Harris, is not an application of so-called Younger abstention as that doctrine is now understood, though the holding is consistent with certain core principles implicit in the Younger opinion itself. ${ }^{6}$

This Essay touches on several different issues arising from the Harris case. Many merit article-length treatment, which we regrettably cannot provide in this short Essay. We nonetheless deem it useful to raise and reflect on these issues here, even if we cannot hope to put them to rest.

Part I of this Essay will examine the proper weight that remedial equitable principles should have in federal court decisions to grant or deny injunctive relief. $^{7}$ We maintain that structural values of federalism and separation of powers can and should be considered by federal courts asked to enjoin state legal proceedings. The remedial equitable principles that comprise "our federalism," however, are very different from the Younger doctrine as it has been articulated by the Supreme Court. Remedial equitable considerations of federalism alone do not warrant a near-blanket rule against enjoining state legal proceedings, as is now mandated by the Younger doctrine. Rather, federalism, along with other structural constitutional principles, is only one relevant factor in equitable balancing by federal courts. We thus argue that a focus on remedial equitable principles requires significant and long overdue reductions in the scope of the Younger doctrine. ${ }^{8}$

In Part II, we explain why Harris' failure, after multiple filings, to raise constitutional objections to his method of execution before April 17, 1992, was by itself sufficient reason, on equitable grounds, to rule an injunction in his favor an abuse of discretion. We argue that the propriety of Harris' delay must be judged by reference to the law at the time his claim first could have been brought rather than by subsequent legal developments. We further contend that even if subsequent fortuitous legal developments can, in hindsight, sometimes

6. See Younger v. Harris, 401 U.S. 37 (1971).

7. The contributions of Judge Reinhardt and Professors Caminker and Chemerinsky ably summarize the important events in the Harris case, and we therefore describe those events only when necessary.

8. In view of the Supreme Court's steady expansion of that doctrine over the past two decades, the case for optimism on this score is admittedly not strong. 
excuse delay in bringing claims, Harris and his counsel could not properly benefit from that principle.

In Part III, we comment briefly on the role of executive clemency in handling inexcusably delayed claims in capital cases. In Part IV, we discuss some issues raised by the Supreme Court's extraordinary April 21, 1992, order that "[n]o further stays of Robert Alton Harris' execution shall be entered by the federal courts except upon order of this Court." We agree generally with Professors Caminker and Chemerinsky's excellent argument that this order is very troubling and, if taken at face value, was issued without authority.

Finally, in Part V, we reflect on some of the lessons of the Harris episode for courts and scholars, with particular attention to the appropriate role of the Supreme Court in reviewing highly specific grants or denials of equitable relief by inferior federal courts. We discuss the nature of the federal judicial hierarchy and conclude that the structural values represented by that hierarchy-like the structural values of federalism and separation of powers-must inform the Supreme and inferior federal courts' exercise of their remedial equitable discretion. These principles suggest that the Court was correct to intervene in Harris and to withold action in the French abortion pill dispute, but wrong to intervene in the Haitian case by staying the inferior court's judgment that forbade the return of Haitian refugees.

\section{I.}

In its per curiam opinion of April 21, 1992, vacating two stays of execution entered on the previous day by various judges of the Ninth Circuit, the Supreme Court gave two grounds for its action. First, the Court stated that Harris' eleventh-hour claim, following four prior federal habeas petitions, "is an obvious attempt to avoid the application of McCleskey $v$. Zant to bar this successive claim for relief."10 Second, the Court concluded that whether Harris' claim was properly characterized as a $\$ 1983$ claim or as a habeas petition, equitable principles precluded relief. ${ }^{11}$ The first ground is dubious, for many of the reasons offered by Professors Caminker and Chemerinsky. ${ }^{12}$ The second ground, however, is entirely correct and raises important issues that go beyond Harris' execution.

9. Vasquez v. Harris, 112 S. Ct. 1713, 1714 (1992) (No. 5).

10. Gomez v. United States Dist. Court, 112 S. Ct. 1652, 1653 (1992) (citation omitted).

11. ld.

12. Caminker \& Chemerinsky, supra note 5, at 248-52. In particular, as they point out, if the Court was adopting a rule for the recharacterization of $\S 1983$ claims as habeas petitions for purposes of $M c$ Cleskey, the Harris case, involving an eleventh-hour stay application without oral argument or full briefing, was a bizarre vehicle for such adoption. Id. at $239 \mathrm{n}$.78. If the Court was not adopting such a rule, it is hard to understand why it chose to mention the issue at all, since the the Court clearly viewed the second ground as dispositive. 
The Court's explanation of why equitable principles barred relief for Harris bears quotation in full:

Even if we were to assume, however, that Harris could avoid the application of $\mathrm{McCl}$ eskey to bar his claim, we would not consider it on the merits. Whether his claim is framed as a habeas petition or a $\S 1983$ action, Harris seeks an equitable remedy. Equity must take into consideration the State's strong interest in proceeding with its judgment and Harris' obvious attempt at manipulation. This claim could have been brought more than a decade ago. There is no good reason for this abusive delay, which has been compounded by last-minute attempts to manipulate the judicial process. A court may consider the last-minute nature of an application to stay execution in deciding whether to grant equitable relief. ${ }^{13}$

This rationale differs somewhat from the rationale offered by Judges Alarcon and Brunetti in their April 20 order vacating Judge Patel's restraining order against Harris' execution. ${ }^{14}$ The Ninth Circuit panel relied exclusively on the argument "that the district court lacked the jurisdiction to enjoin the execution of the state court's judgment under the principles of federalism and comity first announced in Younger v. Harris." "Th Supreme Court's per curiam opinion made no reference to Younger, to subsequent cases applying the so-called Younger doctrine, or to the jurisdiction of the inferior courts. The Court's failure to invoke Younger or to discuss jurisdictional issues provides an excellent opportunity to reconsider the justly-maligned Younger doctrine and to rethink the law of federal-state relations.

Over the past two decades, the Younger doctrine has evolved into a bizarre web of judge-made exceptions (and exceptions to the exceptions) to federal court authority in cases involving state legal proceedings. ${ }^{16}$ The resulting edifice is difficult to understand and even more difficult to justify, whether as a matter of constitutional law, statutory interpretation, political theory, or common sense. ${ }^{17}$

There is, however, a small kernel of truth buried in Younger that deserves reclamation and that is well-illustrated by the Harris case itself. As the Court's per curiam order noted, Harris sought an equitable remedy. The grant of equitable relief to a litigant, such as an injunction, is not a matter of right; even

13. Gomez, 112 S. Ct. at 1653 (citations omitted).

14. An appellate court is of course free to affirm a lower court judgment on any ground properly supported by the record.

15. Gomez v. United States Dist., No. 92-70237, 1992 U.S. App. LEXIS 7931, at *3 (9th Cir. Apr. 20,1992 ) (citation omitted), vacated as moot and withdrawn, 1992 U.S. App. LEXIS 10088 (9th Cir. May 5, 1992), modifying 1992 U.S. App. LEXIS 8857 (9th Cir. Apr. 22, 1992).

16. See generally ERWIN CHEMERINSKY, FEDERAL JURISDICTION 621-55 (1989); MARTIN H. REDISH, FEDERAL JURISDICTION: TENSIONS IN THE ALLOCATION OF JUDICIAL POWER 337-55 (2d ed. 1990).

17. For an excellent critique of the Younger doctrine, see MARTIN H. REDISH, THE FEDERAL COURTS IN THE POLITICAL ORDER: JUDICIAL JURISDICTION AND AMERICAN POLITICAL THEORY 47-49, 55-60 (1991). 
a litigant with an airtight case on the merits is not entitled to injunctive relief if traditional equitable considerations counsel against it. ${ }^{18} \mathrm{~A}$ variation on this well-established remedial principle was at the heart of the Younger opinion (though Younger's application of that principle is subject to question). Contrary to some modern perceptions and case law, Younger did not require or offer a textual justification for abstention from jurisdiction; it required abstention from equitable relief in certain circumstances. Nothing in Younger expressly stated that lower courts have no jurisdiction to entertain claims concerning ongoing state criminal proceedings. ${ }^{19}$ Rather, it held only that federal courts should not equitably intervene against ongoing state proceedings. ${ }^{20}$ This distinction between jurisdictional and remedial principles is of enormous theoretical importance, and of enormous practical importance if its implications are properly appreciated.

If one views Younger abstention as a judge-made exception to federal jurisdiction, one must explain, as the Supreme Court has not done, where federal courts derive the power to refuse to exercise jurisdiction-properly conferred on them by federal law. ${ }^{21}$ If, however, one views it simply as an application of remedial principles, this jurisdictional separation of powers problem does not arise. In the words of then-Judge Scalia, "[t]he ability to decide a case has nothing to do with the propriety of granting an extraordinary and discretionary remedy."22 The correct core principle of Younger is thus that considerations of federalism - and, perhaps by implication, other structural concerns such as separation of powers and the nature of the judicial

18. As a threshold requirement, the litigant must also have no adequate remedy at law. This issue was not addressed by the Court.

19. Whether federal courts have jurisdiction to hear claims concerning ongoing state proceedings is a different question from whether the claims in Younger presented a live case or controversy. See Younger v. Harris, 401 U.S. 37,42 (1971):

[A]ppellees Dan, Hirsch, and Broslawsky do not claim that they have ever been threatened with prosecution, that a prosecution is likely, or even that a prosecution is remotely possible. They claim the right to bring this suit solely because, in the language of their complaint, they "feel inhibited." We do not think this allegation, even if true, is sufficient to bring the equitable jurisdiction of the federal courts into play ....

20. See id. at 53. This, of course, is a holding of no small moment, and if interpreted too broadly, it is certainly wrong. See infra text accompanying notes $35-45$. But it has nothing to do with the jurisdiction of the federal courts.

21. See REDISH, supra note 17, at 47; Gerald Gunther, The Subtle Vices of the "Passive Virtues"-A Comment on Principle and Expediency in Judicial Review, 64 COLUM. L. REV. 1, 16 (1964). Cf. Antonin Scalia, The Doctrine of Standing as an Essential Element of the Separation of Powers, 17 SUFFOLK U. L. REV. 881, 885 (1983) (expressing doubts about doctrine of prudential standing, "not least because it leaves unexplained the Court's source of authority for simply granting or denying standing as its prudence might dictate"). The same problem is raised when federal courts imply or assume jurisdiction beyond that granted to them by statute.

22. Ramirez de Arellano v. Weinberger, 745 F.2d 1500, 1562 (D.C. Cir. 1984) (en banc) (Scalia, J., dissenting), vacated and remanded, 471 U.S. 1113 (1985). 
hierarchy-are factors to be weighed in the remedial equitable balance by federal courts asked to enjoin state proceedings. ${ }^{23}$

Then-Judge Scalia's dissenting opinion in Ramirez de Arellano v. Weinberger illustrates this principle in a separation of powers context. Ramirez sought to enjoin a joint American-Honduran military training exercise in Honduras on the ground that the exercise, part of which took place on his cattle ranch, effected a taking of his property. Judge Scalia dissented from the D.C. Circuit's reversal of the trial court's dismissal of the complaint in part because separation of powers concerns rendered an injunction against United States military operations inappropriate. A representative portion of his reasoning is instructive:

The most important point is that the plaintiffs are asking for direct court interference with a military operation being conducted abroad. ... While it is acknowledged that the land in question is being used for a training base, we do not know what other military purposes it may be designed to serve. If, for example, it had been the staging area for our recent military operations in Grenada, the injunction sought here could have caused incalculable harm. The majority's apparent belief that the trial court should hold a hearing on exactly how harmful to our foreign and defense policies an injunction would be is absurd. Even assuming that we are competent judges of such matters, which we are not, we cannot expect or require the Commander-in-Chief to take us (much less the plaintiffs) into his confidence regarding the activities now in hand. And without such knowledge, the fact is that we have no idea what damage to our national interests the discretionary and extraordinary relief sought here might produce. A proper understanding of equitable principles, informed by respect for the separation of powers, should lead us simply and abruptly to deny such relief. ${ }^{24}$

23. One possible formalist rationale for a jurisdictional rather than remedial underpinning for the Younger doctrine-which, if correct, would vindicate the doctrine but not the judge-made exceptions to it-would be that the "judicial Power of the United States" simply does not extend to suits in equity against states or state officials (though, on this understanding, the jurisdictional grants in Article III permit states to bring suits in federal court). In that case, there could not be, consistent with Article III, a valid federal jurisdictional statute authorizing such relief. This principle, of course, would extend far beyond the context of ongoing state proceedings and would forbid any federal equitable suits against any state action- which seems extraordinary. Nonetheless, a related construction of Article III may underlie and explain some of the Court's recent Eleventh Amendment jurisprudence. See Pennsylvania v. Union Gas Co., 491 U.S. 1 (1989). Discussion of this point would take us far afield, and we do not believe that such constructions of Article III are tenable. See U.S. CoNST. art. III, § 2 ("The judicial power shall extend . . to Controversies between two or more states."); Chisholm v. Georgia, 2 U.S. (2 Dall.) 419, 464 (1793) (Wilson, J.); Akhil Reed Amar, Of Sovereignty and Federalism, 96 YALE L.J. 1425 (1987); Lawrence C. Marshall, Fighting Words of the Eleventh Amendment, 102 HARV. L. REv. 1342 (1989). Cf. Marbury v. Madison, 5 U.S. (1 Cranch) 137 (1803); Ex parte Young, 209 U.S. 123 (1908). One might also argue, as did some nineteenthcentury writers, that the judicial power of federal courts of equity does not extend to suits to enjoin certain state court proceedings. Younger did not address this argument, and we cannot pursue it in this brief Essay.

24. Ramirez, 745 F.2d at 1561 (citations omitted). 
Judge Scalia did not claim that the court's injunction was affirmatively unconstitutional on separation of powers grounds, nor did he believe that the case raised a nonjusticiable political question. ${ }^{25}$ His point instead was that structural separation of powers concerns should strongly inform a court's discretionary decision to grant or deny equitable relief, and that these concerns were "strong enough to make the] injunction [in Ramirez] an abuse of discretion." the federal courts have long recognized, structural federalism concerns should be considered in an equitable balance. ${ }^{27}$

This suggestion raises at least two important questions. First, what is the effect of congressional statutes, such as the Anti-Injunction Act, which expressly forbid injunctive relief in particular cases? ${ }^{28}$ Second, is it in fact legitimate, as a matter of first principles, for federal courts to take structural considerations into account in making judgments about equitable relief, and if it is legitimate in principle, how do these considerations figure in an equitable balance, particularly in light of the federal judiciary's historic role as a prime guardian of nationally-protected individual rights?

The first question raises a threshold problem that, under different circumstances, might preempt most subsequent discussion of federal court authority to enjoin state proceedings. Congress has not left the area of injunctive relief in cases involving state proceedings a blank slate. The aptly-named AntiInjunction Act provides: "A court of the United States may not grant an injunction to stay proceedings in a State court except as expressly authorized by Act of Congress, or where necessary in aid of its jurisdiction, or to protect or effectuate its judgments." 29 On its face, that statute would seem to dispose neatly of most cases in which the Younger doctrine is potentially applicable (though it would not bar Harris' claim, as the state court proceedings had run their course).$^{30}$ In Mitchum v. Foster, ${ }^{31}$ however, the Supreme Court construed 42 U.S.C. $\S 1983$ to be an express authorization of injunctive relief within the meaning of the Anti-Injunction Act. Section 1983 provides, in general terms, that persons alleging deprivations of federal rights under color of state

25. Indeed, he expressly reserved judgment on the injunction's unconstitutionality, see id. at 1562, and he authored the panel opinion that rejected a political question challenge to Ramirez' suit. See Ramirez, 724 F.2d at 147. He did, however, believe that the court lacked jurisdiction because Ramirez' exclusive remedy was a damages action for just compensation in the Claims Court.

26. 745 F.2d at 1563. Ramirez had available a damages remedy in the Claims Court, which he chose initially not to pursue. The unavailability of relief at law is a necessary, though not necessarily a sufficient, condition for the grant of injunctive relief. It is clear that under Judge Scalia's analysis an injunction of the form requested would have been improper even if Ramirez had had no adequate remedy at law.

27. See, e.g., Rizzo v. Goode, 423 U.S. 362, 377-80 (1976) (suggesting in dictum that considerations of federalism counsel against granting equitable relief to control state executive administration).

28. We later consider the effect of federal statutes which expressly authorize injunctive relief in particular cases. See infra note 49 and accompanying text.

29. 28 U.S.C. $\$ 2283$ (1992).

30. But see REDISH, supra note 17, at 168 n.71 (suggesting that broad reading of the "in-aid-of-itsjurisdiction" clause of the Anti-Injunction Act could justify wide range of federal injunctions against state proceedings).

31. 407 U.S. 225 (1972). 
law may bring, inter alia, "suit[s] in equity."32 If that is an "express" authorization to enjoin "proceedings in a State court," Noah Webster and Samuel Johnson should be turning over in their graves. ${ }^{33}$ Nonetheless, the Supreme Court has shown no inclination to revisit Mitchum, ${ }^{34}$ and so our discussion proceeds on the assumption that the Anti-Injunction Act poses no bar to federal court injunctions against state court proceedings in any federal civil rights case.

The second question concerns the propriety of courts taking structural concerns into account when determining whether to grant equitable relief in particular cases. "The judicial Power of the United States" conferred by Article III grants to federal courts hearing cases "in Equity" the power to apply traditionally accepted remedies in properly presented cases. ${ }^{35}$ This constitutional grant of remedial power is also part of the background against which all federal statutes (including those that purport to control the exercise of remedial authority) are enacted ${ }^{36}$ Traditionally, the decision to grant or deny equitable relief has turned on such factors as the adequacy of remedies at law, unclean hands, the likelihood of success on the merits, and a balance of hardships. How do structural constitutional considerations that do not necessarily rise to the level of constitutional violations ${ }^{37}$ fit into this picture? In other words, where do federal courts get the authority to consider such factors if they were not part of the British tradition of equity that we inherited?

The answer is that American federal courts are not British courts. The power of federal courts stems from the Constitution. That document, which

32. 42 U.S.C. § 1983 (1992).

33. The Court even acknowledged that it was crafting an "implied" exception[] to the blanket prohibition of the anti-injunction statute." 407 U.S. at 235. As Professor Redish has noted, an "implied" express exception is "an oxymoron if ever there was one . . ." REDISH, supra note 17, at 58 .

34. Whether Mitchum and the Younger line of cases can or should be overruled in light of the principle of stare decisis is a question beyond the scope of this Essay.

35. If the federal courts' remedial powers indeed flow to this extent from Article II, then statutes such as the Anti-Injunction Act raise interesting and complex questions about congressional power to regulate the remedial activities of the federal courts. Congress, can, in a sense, control the exercise of the courts' remedial power by controlling (to the extent permitted by the Constitution) the jurisdiction of particular federal courts. But it does not follow that this greater power over jurisdiction includes the lesser power to place conditions on the exercise of that jurisdiction by all federal courts, as the Anti-Injunction Act does. Congress' power to control the manner in which courts decide cases, and hence the manner in which they fashion remedies, must stem from its power to pass laws "which shall be necessary and proper for carrying into Execution ... . all . . . Powers vested by this Constitution in the Government of the United States, or in any Department or Officer thereof." U.S. CONST. art. I, \$ 8, cl. 18. If "the judicial Power" truly includes a core power to issue certain equitable remedies, it is difficult to see how a law restricting that power is a law "for carrying into Execution" the judicial power. Similar questions would arise if Congress passed a statute, for example, forbidding federal courts from considering the doctrine of unclean hands when deciding whether to issue injunctions. Obviously, we cannot explore these important questions or the case law addressing them here, though we hope to do so in a subsequent article.

36. See Paul Bator, The State Courts and Federal Constitutional Litigation, 22 WM. \& MARY L. REV. $605,622 \mathrm{n} .49$ (1981) (discussing role of equitable principles as statutory background).

37. Obviously, one can imagine injunctions, whether or not expressly authorized by Congress, that intrude so deeply into federalism or the separation of powers that they are affirmatively unconstitutional, even if the cases that present them do not raise nonjusticiable political questions. Our concem, however, is with injunctions that implicate these structural principles without violating them. 
launched "a new order for the ages,"38 is infused throughout with considerations of governmental structure. ${ }^{39}$ Federalism, separation of powers, and checks and balances all work to create a pluralist regime of divided power, with the object of making "the private interest of every individual . . . a sentinel over the public rights." ${ }^{\prime 40}$ These structural considerations have influenced, and should influence, other legal doctrines, particularly the "tradition" of equity that is appropriate for distinctly American federal courts. Just as the freedom of speech protected by the First Amendment draws on, but need not be limited to, the freedom of speech as it was understood in England in 1791, so the remedial equitable powers of federal courts need not be limited to the particular checklist of factors that would have been legitimate for English chancery courts to consider in $1789 .{ }^{41}$ If a structural value can properly be derived from the federal Constitution, it will necessarily have a bearing on exercises of power by federal equity courts. Federalism (along with the separation of powers) has long been recognized as such a structural value. ${ }^{42}$ No one, we trust, would think that federal courts are obligated to grant injunctive relief in every challenge to the outcome of a state suppression hearing, even when the courts have jurisdiction over the claim in the strict sense of the term. ${ }^{43}$ The only source of authority for federal courts to refuse to intervene in these proceedings, when they are clearly granted jurisdiction, is their ability to consider the federalism implications of their actions. There comes a point at which dual federalism simply cannot be ignored, and under the principles articulated in Younger, the logical place-indeed the only place-to take account of that fact is in the

38. FORREST MCDONALD, NOVUS ORDO SECLORUM: THE INTELLECTUAL ORIGINS OF THE CONSTTTUTION (1985).

39. See Steven G. Calabresi \& Kevin H. Rhodes, The Structural Constitution: Unitary Executive, Plural Judiciary, 105 HARV. L. REV. 1153, 1155-56 (1992); Steven G. Calabresi, Note, A Madisonian Interpretation of the Equal Protection Doctrine, 91 YALE L.J. 1403 (1982).

40. THE FEDERALIST No. 51, at 322 (James Madison) (Clinton Rossiter ed., 1961). See also id. ("This policy of supplying, by opposite and rival interests, the defect of better motives, might be traced through the whole system of human affairs, private as well as public."). Cf. ADAM SMTTH, AN INQUIRY INTO THE NATURE AND CAUSES OF THE WEALTH OF NATIONS 419 (Edwin Canaan ed., 5th ed. 1930) ("It is not from the benevolence of the butcher, the brewer, or the baker that we expect our dinner, but from their regard for their own interest.").

41. Indeed, it would actually be counterhistorical to limit American courts of equity to the checklist of factors that would have been appropriate for British courts in 1789 , while forbidding them to take account of the peculiar features of their own underlying, constituting document. It is precisely the nature of equity, as opposed to law, to be flexible enough to accommodate a change in circumstances of this kind. That is not to say that every claimed "evolution" of equitable principles unratified by "We the People" could be comparably legitimate.

42. Other structural values implicit in our Constitution include a greater preference for both democracy and for judicially enforced individual rights than was typical in England 200 years ago. All of these structural principles are plainly integral parts of the system of government set forth in the Constitution-unlike free-floating "equitable" values such as sympathy for a particular party or outlook. We therefore do not believe that equity is wholly open-ended and can include factors not derivable from either tradition or the structure of the Constitution.

43. Even the Court in Dombrowski v. Pfister, 380 U.S. 479 (1965), which took the extraordinary step of enjoining state prosecutions that had not yet been brought, acknowledged the inappropriateness of this kind of piecemeal intervention in evidentiary matters. Id. at 484 n.3. 
exercise of equitable discretion. The remedial principle emphasized by Judge Scalia in Ramirez, extended to embrace federalism concerns, is thus a sound deduction from the structure of the American constitutional order. ${ }^{44}$

That does not, of course, tell us how heavily federalism values should weigh in an equitable balance-or even on what side of the scale they ultimately fall in any given case. Federalism, after all, has both a localist and a nationalist dimension. Arguments for a state's autonomy and ability to carry out judgments with certainty and finality ${ }^{45}$ can be countered by equally compelling arguments for national supremacy and the need for federal protection of federal statutory and constitutional rights. In this brief Essay, we make only four preliminary observations.

First, Younger (and subsequent cases) have clearly misapplied this equitable principle of federalism by announcing, without serious analysis, a near-blanket rule against injunctions that interfere with state proceedings. ${ }^{46}$ As noted above, to say that federalism concerns are relevant to the decision to grant or deny injunctive relief is not to say that they are decisive-much less that they are always decisive in favor of the state. The judgment that federalism concerns are so important that injunctions should be denied in all such cases as a matter of course requires far more argument than was provided in Younger or subsequent decisions. ${ }^{47}$ Any doctrine of remedial absention that emerges from this analysis will undoubtedly be far narrower than the existing Younger doctrine.

Second, cases following Younger have occasionally cast Younger abstention in jurisdictional terms, as the Ninth Circuit Panel did in Harris. ${ }^{48}$ Thus, the Younger doctrine, even if not the Younger opinion, often purports to circumscribe the jurisdiction of the federal courts. This interjection of jurisdictional concerns, unsupported by an articulated construction of Article III, draws

44. Cf. Ann Althouse, How to Build a Separate Sphere: Federal Courts and State Power, 100 HaRV. L. REV. 1485, 1531-34 (1987) (suggesting that federalism principles are distinct from equitable principles, and arguing that both sets of principles can and should inform decisions to grant or deny injunctive relief against state officials).

45. This is not an insignificant interest. Our constitutional order clearly gives the states primary responsibility for law enforcement, and if the efficacy of a state's criminal justice system depends in part on its ability to carry out its judgments within a reasonable time frame, persistent federal intervention in state proceedings can impair a state's ability to maintain law and order.

46. See REDISH, supra note 17 , at 58.

47. See generally Martin H. Redish, The Doctrine of Younger v. Harris: Deference in Search of a Rationale, 63 CORNELL L. REV. 463 (1978) (critically discussing extant rationales for strong deference rule of modern Younger doctrine). Cf. Ralph U. Whitten, Federal Declaratory and Injunctive Interference with State Court Proceedings: The Supreme Court and the Limits of Judicial Discretion, 53 N.C. L. REV. 591, 613 (1975) (suggesting that federalism concerns may be relevant to granting injunctions, but urging that equitable concerns be made explicit).

48. Compare, e.g., Huffman v. Pursue, Ltd. 420 U.S. 592, 612 (1975) ("We therefore think that this case is appropriate for remand so that the District Court may consider whether ... [the relevant injury] is of such a nature that the District Court may assume jurisdiction under an exception to the policy against federal judicial interference with state court proceedings of this kind.") (emphasis added) with Ohio Civil Rights Comm'n v. Dayton Christian Schls. Inc., 477 U.S. 619, 626 ("[Younger abstention] does not arise from lack of jurisdiction in the District Court, but from strong policies counseling against the exercise of such jurisdiction where particular kinds of state proceedings have already been commenced."). 
attention away from the genuine, remedial questions that underlie the decision to grant federal injunctions against state officials.

Third, the problem of properly weighting factors in equitable balancing is difficult, but it is no more difficult for federalism values than for doctrines such as unclean hands. Equitable balancing is, after all, balancing, and there is no algorithm to specify how that balance must be reached. Federalism and separation of powers concerns, however, may provide less room for the exercise of judicial discretion in equitable balancing than do other factors. Federalism and separation of powers are not free-floating values. The Constitution contemplates a specific structural scheme, and that particular scheme rather than a theoretical model should inform the equitable discretion of courts.

Fourth, it is important to consider the extent to which Congress can affect, and has tried to affect, the manner in which the equitable balance should be struck by federal courts. One can argue, for example, that it would be improper for federal courts to take account of federalism concerns in suits for injunctions under $\$ 1983$ because Congress already struck the appropriate federalism balance when it passed the statute. If Congress indeed tried to forbid the federal courts from taking account of some equitable factor that they would otherwise be entitled to weigh under their Article III judicial power, it would raise serious questions about the constitutional source and scope of such congressional power. Apart from the various anti-injunction statutes which forbid injunctive relief altogether in certain classes of cases, however, we do not think that Congress has spoken clearly enough to raise these questions. By passing statutes that authorize injunctive relief against states or state officials, Congress has plainly struck the federalism balance as a matter of substantive constitutional practice, but it is not clear that it has also struck the balance as a matter of remedial discretion. As we have indicated, it would certainly be inappropriate-an abuse of remedial discretion-for federal courts to adopt an absolute or near-absolute rule against enjoining states or state officials, but it does not follow that courts must, or should, consider it irrelevant that a state or state official is the intended target of equitable relief. Younger-style remedial abstention is wrong, but a measured regard for principles of federalism-favoring exclusively neither the national nor the state governments-is not. To say that $\S 1983$ authorizes federal courts to employ their Article III equitable powers against states is not to say that it requires them to do so in all circumstances: $\S 1983$ is not a "Pro-Injunction Act."49

To return to Harris' claim, the Supreme Court was therefore on firm ground when it said that "[e]quity must take into consideration the State's strong

49. If one views federalism as a background principle against which federal legislation is enacted, the weight to be given to the principle may vary over time. A federal statute authorizing injunctive relief against state officials in 1795 may have operated against very different background principles than a similar statute enacted in 1868. We are indebted to Marty Redish for this important point. 
interest in proceeding with its judgment $\ldots . .500$ Of course, that does not mean, and the Court did not claim, that this state interest alone was strong enough to warrant denial of Harris' injunction - much less reversal of the trial court's grant of that injunction. A judgment of that kind no doubt requires a more careful balancing of the equities. But it does mean, as Professors Caminker and Chemerinsky acknowledge, ${ }^{51}$ that the Court was focusing on the relevant considerations and was asking the right questions. The principal legal issue raised by Harris' appeal thus does not involve the law of either capital punishment or federal jurisdiction. It involves the law of remedies.

II.

The federalism concerns represented by the State of California's interest in its judgment are not the only, or the most important, equitable considerations relevant to Harris' claim. The dominant factor in this proceeding was clearly the lateness of Harris' request for relief-especially in light of his failure to raise constitutional objections to his method of execution in four previous federal habeas petitions and five state petitions brought over a period of years. On its face, in the absence of further justification for delay, this is an eminently sensible ground for denying an injunction. More to the point for the Harris case, the delay appears to have constituted such an abuse of the judicial process that Judge Patel at least arguably abused her discretion by granting an injunction. ${ }^{52}$ One should thus be cautious before attributing improper motives to the Supreme Court. ${ }^{53}$

50. Gomez, 112 S. Ct. at 1653.

51. Caminker \& Chemerinsky, supra note 5 , at 239.

52. If Younger is not a jurisdictional doctrine, however, then there is a question whether mandamus was an appropriate vehicle for the Ninth Circuit panel's review of Judge Patel's order. The trial court's decision to grant an injunction, even if wrong, was discretionary, and mandamus should ordinarily be available only to compel performance of ministerial tasks or to correct jurisdictional defects (although many modern cases extend mandamus even to some discretionary decisions). If mandamus was inappropriate (and it is not clear under modern authority whether it would be), and if Judge Patel's order is best characterized as a temporary restraining order rather than a preliminary injunction, then one could argue that her order was simply unappealable. See 2 CHARLES A. WRIGHT \& ARTHUR R. MILLER, FEDERAL PRACTICE AND PROCEDURE § 2962 (1973) ("[A]lthough preliminary injunctions are appealable under [28 U.S.C. § 1292(a) (1992)], it generally has been held that temporary restraining orders are not.") (footnotes omitted). This conclusion is hard to square with the language and structure of $\$ 1292$, which generally authorizes appellate review of district court orders "granting, continuing, modifying, refusing or disolving injunctions, or refusing to dissolve or modify injunctions," 28 U.S.C. $\$ 1292$ (a)(1), but we cannot address here the relationship between temporary restraining orders and injunctions or the appropriate role of mandamus in federal appellate review. It is possible, however, that there is a wider scope for mandamus within the judicial hierarchy, see infra Part V, than when courts are controlling the actions of officials of a coordinate department of government such as the executive.

53. To say that Judge Patel's actions were, as a matter of law, an abuse of discretion is not to say that she, or Harris' counsel, behaved wrongly or irresponsibly. It is merely to say that the governing law did not (as the Supreme Court concluded) support Harris' claim for an injunction. Judge Patel may have behaved reasonably, given her view of the relevant Eighth Amendment law. But given the actual state of the law, her actions were an abuse of discretion. This case does not turn on the bad faith of Judge Patel or Harris' counsel, but on the objective appropriateness of this injunction in this case at this time. For the reasons we 
Professors Caminker and Chemerinsky, however, insist that Harris' delay in bringing his Eighth Amendment challenge to California's method of execution was justifiable ${ }^{54}$ and thus did not merit denial of an injunction, much less reversal of Judge Patel's order. Their argument turns on the nature of Harris' claim. Harris contended that the gas chamber is a "cruel and unusual" method of execution in violation of the Eighth Amendment. Professors Caminker and Chemerinsky emphasize the Supreme Court's oft-repeated statement that the meaning of the Eighth Amendment is determined by the evolving standards of decency that mark the progress of a maturing society." ${ }^{\text {"55 }}$ The case for a changed attitude toward the gas chamber, they argue, matured, or at least gained significant strength, in the period shortly before Harris' execution. Four of the seven states that still authorized use of the gas chamber in 1983 had abandoned it by the time of Harris' execution. Only California, Maryland, and Arizona continued to sanction gas chamber executions. Maryland has not recently employed its capital sanction. Arizona utilized the gas chamber on April 6, 1992, just two weeks before Harris' execution, but the State's Attorney General immediately thereafter called for abandonment of that mode of execution and efforts were made in the state legislature to change the law. Hence, claim Professors Caminker and Chemerinsky, "Harris' position on the merits became significantly stronger over the past decade," reasonable for Harris' counsel to bring his claim on the eve of execution.

Assuming that the content of the Eighth Amendment evolves with judicially discerned changes in societal standards of decency-another question beyond the scope of this Essay-this argument does not hold up, either in principle or on the facts of Harris. As a matter of principle, it improperly judges actions by hindsight. Suppose for the moment that Harris' claim really was stronger on April 17, 1992 than it would have been a decade earlier. That does not answer the relevant question, which is when Harris or his counsel should have brought the claim. That question can only be answered ex ante rather than ex post. Ex ante, the claim should have been brought within a reasonable time of its accrual-that is at the first opportunity. Just as a statute of limitations runs from the accrual of a cause of action, and is not tolled by the possibility of discovering new and better evidence in the future, so, we argue, an equitable "statute of limitations" on Eighth Amendment claims-under the rubric of laches-should run from accrual of the claim. It is true that some claims may grow stronger over time, and therefore may suffer as a result of this rule, but other claims will grow weaker over time and thus will benefit from earlier presentation. In view of the fact that the general public favors the death penalty by a four-to-one margin, it is hardly inconceivable that the evolution of societal

explain below, the Supreme Court correctly found and applied the law; Judge Patel did not.

54. Caminker \& Chemerinsky, supra note 5 , at 240.

55. Penry v. Lynaugh, 492 U.S. 302, 330-31 (1989) (citation omitted).

56. Caminker \& Chemerinsky, supra note 5 , at 241 . 
norms may develop in a fashion unfavorable to capital defendants. ${ }^{57}$ Harris' execution could, for example, cause other states to employ the gas chamber, in which case lawyers now waiting for an Eighth Amendment challenge to the gas chamber to grow stronger will have erred. In any event, the law cannot operate on such ex post contingencies and speculations. ${ }^{58}$ Harris' claim could have been brought upon conviction, or at the latest in 1983 when three Justices expressed constitutional doubts about the gas chamber. There was therefore more than enough delay to render equitable relief inappropriate. The death penalty, however different from other punishments, must be administered under the rule of law.

But this discussion gives too much weight to the argument that societal evolution made Harris' legal claim "significantly stronger"s9 in the time before his execution and thus justified-even on an ex post basis-his delay until April 17, 1992. In fact, Harris' claim was a sure loser in 1982, and it did not improve with age.

In 1983, seven states authorized use of the gas chamber. ${ }^{60}$ Thus, even if one could have demonstrated in 1983 that this method of execution was "cruel," it certainly was not then "unusual," and therefore could not violate the Eighth Amendment. ${ }^{61}$ By April 17, 1992, two things had changed that Professors Caminker and Chemerinsky find relevant to Harris' claim. First, only three states still authorized use of the gas chamber. Second, the Arizona Attorney General called for abolition of the gas chamber shortly after Arizona used it to execute a criminal on April 6,1992, and a bill to abolish the gas chamber was introduced in the state legislature. Consequently, Professors Caminker and Chemerinsky argue, "Harris' claim did not fully mature," 62 and thus need not have been brought, until April 6, 1992. Neither event justified Harris' delay, even when improperly viewed from an ex post perspective.

First, it is doubtful whether a traditional mode of execution employed by three states, one of which contains roughly one-eighth of the nation's popula-

57. Cf. Thompson v. Oklahoma, 487 U.S. 815, 864-872 (1988) (Scalia, J., dissenting) (arguing, in response to plurality statement that defendants under eighteen years of age cannot constitutionally be subject to death penalty, that societal evolution suggests, if anything, a lowering of age at which criminal defendants can properly be eligible for capital punishment).

58. If one assumes, contrary to all evident facts, that societal evolution works uniformly in favor of capital defendants, then of course all claims should be held for the last minute. Who knows, after all, what new evidence of evolution will turn up? This seems to us to create a very poor set of litigation incentives and to foreordain the evolution that is anticipated.

59. Caminker \& Chemerinsky, supra note 5, at 241.

60. See Gray v. Lucas, 463 U.S. 1237, 1246 n.8 (1983) (Marshall, J., dissenting) (listing the seven states that still authorized use of gas chamber at that time).

61. See Stanford v. Kentucky, 492 U.S. 361, 369 (1989) ("[T] he language of the [Eighth] Amendment .. . proscribes only those punishments that are both "cruel and unusual.") (emphasis in original). The Justices in Gray v. Lucas who expressed doubts about the constitutionality of the gas chamber focused entirely on the element of cruelty; they did not discuss the constitutional requirement that invalid punishments also be "unusual." See Gray v. Lucas, 463 U.S. at 1240 (Marshall, J., dissenting).

62. Caminker \& Chemerinsky, supra note 5, at 243. 
tion, ${ }^{63}$ can be deemed "unusual" for constitutional purposes. ${ }^{64}$ Second, the move from seven states employing the gas chamber in 1983 to three states in 1992 can hardly be unambiguously attributed to societal evolution. As Professors Caminker and Chemerinsky point out ${ }^{65}$ at least two, and possibly three, Justices expressed doubts about the constitutionality of the gas chamber in $1983 .^{66}$ It seems likely that some states abandoned the gas chamber less out of an evolving sense of decency than out of fear of litigation and further delay in executions. The decline in the past decade in the use and authorization of the gas chamber may thus reflect the evolving preferences of anti-death-penalty Justices rather than being an accurate barometer of social norms. Even if one accepts the decreased use of the gas chamber as reliable evidence of social, rather than judicial, disapproval, this does not explain why Harris' claim had to be brought on the eve of his execution. In order to justify Harris' last-minute filing, Professors Caminker and Chemerinsky must rely on the events surrounding the Arizona execution of April 6,1992. Indeed, they explicitly argue that Harris' claim did not "mature" until that event, ${ }^{67}$ and they insist that Harris' claim "gained measurable force from Arizona's experience a mere two weeks prior to Harris" scheduled execution ....."68

It is hard to see how an execution in the gas chamber two weeks before Harris' execution can support a claim that use of the gas chamber is "unusual." Nor does the subsequent opinion of the Arizona Attorney General, who is merely one government official, demonstrate the necessary consensus within Arizona that the gas chamber is an inappropriate mode of execution. And if we are to consider the views of individual executive officials, then we must also give strong consideration to the statements and actions of Pete Wilson, the elected governor of a state with eight times the population of Arizona, ${ }^{69}$ who never wavered in his support for Harris' death by asphyxiation. The pendency in the Arizona legislature of a bill to change that state's mode of execution also does not make Harris' claim more plausible, because the law authorizing use

63. According to the 1990 census, the total population of the United States is $248,709,873$ persons, of whom 29,760,021 live in California. See THE WORLD ALMANAC AND BOOK OF FACTS 1992 74-75 (1992).

64. We cannot fully address here the proper interpretation of the word "unusual" in the Eighth Amendment. Assuming that the meaning of the Eight Amendment evolves, however, both the number of states that authorize a practice and the size of those states are relevant in determining the unusualness of a punishment. $C f$. Reynolds v. Sims, 377 U.S. 533, 560-61 (1964) (indicating that political representation must be apportioned on basis of population). Indeed, in view of the Constitution's establishment of a legislative department consisting of both a branch based on population (the House) and a branch providing equal suffrage for the states (the Senate), it seems to us a fair structural inference that one could only find a national consensus that a punishment is "unusual" if it were authorized both by a small number of states and a small percentage of the citizenry.

65. Caminker \& Chemerinsky, supra note 5, at 241.

66. See Gray v. Lucas, 463 U.S. 1237, 1237 (1983) (Stevens, J., dissenting from denial of stay); id. at 1240 (Marshall, J., and Brennan, J., dissenting from denial of certiorari).

67. Caminker \& Chemerinsky, supra note 5, at 243.

68. Id. at 241 .

69. According to the 1990 census, Arizona's population is $3,665,228$ and California's is $29,760,021$. THE WORLD ALMANAC AND BOOK OF FACTS 1992 74-75 (1992). 
of the gas chamber in Arizona remains on the books. ${ }^{70}$ The Eighth Amendment forbids punishments that are "cruel and unusual," not punishments that are "cruel and controversial."

Even with the benefit of hindsight, there was no justification for Harris to wait until April 17, 1992, to bring his claim. The only remaining defense is that refusal to grant an injunction is too harsh a decree in view of the consequences. ${ }^{71}$ But that is just a polite way of saying that capital defendants should have an unlimited license to abuse the judicial system. Of course, if one believes that the equities in favor of capital defendants are always infinite, that may seem like a fine principle; courts would be obligated to entertain a neverending stream of new claims, to grant stays until they are heard. But for better or worse, the death penalty is a part of the legal landscape. Capital defendants and their lawyers must obey the rules of the road like everyone else.

III.

Because of the tremendous importance of review by federal courts, it is easy to overlook the fact that other actors in the legal system, in other departments and levels of government, also have obligations and opportunities to consider the constitutional and statutory legality of their actions. Presidents, senators, members of Congress, governors, and state legislators play a role along with federal judges in securing and enforcing our constitutional rights. ${ }^{72}$ It is thus important to note that even a regime that gives delay in bringing claims strong weight in an equitable balance does not wholly prevent lastminute claims from being heard. Indeed, the American legal system has a mechanism that is well designed to accommodate eleventh-hour appeals. That mechanism is executive clemency.

Governors can, of course, grant pardons to, or commute the sentences of, capital defendants for any reason, including constitutional doubts about the prescribed mode of punishment. ${ }^{73}$ Governors are not bound by equitable principles or court rules, and, unlike judges, it is appropriate for them to let considerations of sympathy and mercy affect their decisions. Litigants who want several bites at the apple thus have an available forum even if courts adopt a stern attitude towards excessively late filings.

70. The same is true in California, despite a recent amendment giving capital defendants a choice between the gas chamber and lethal injection.

71. See Caminker \& Chemerinsky, supra note 5, at 244; Reinhardt, supra note 4, at 219-23. Professors Caminker and Chemerinsky also suggest that Harris promoted, perhaps inadvertently, values of judicial restraint by witholding his claim, since courts might never have had to pass on it. See Caminker \& Chemerinsky, supra note 5, at 243. In other words, Harris' constitutional claim may not have been "ripe" until his other claims were passed upon. If followed logically, this argument would counsel in favor of piecemeal, seriatim litigation of all potentially dispositive claims.

72. See generally THE FEDERALIST SOCIETY, WHO SPEAKS FOR THE CONSTITUTION? THE DEBATE OVER INTERPRETIVE AUTHORTY (1992).

73. Harris pursued this remedy without success. 
Of course, the possibility of executive clemency by politically responsive officials is not a substitute for review by tenured federal judges; we do not want to be misinterpreted as suggesting the contrary. Our point is simply that executive clemency is an available supplement to judicial review and may be better suited to handling delayed claims than the formalized, cumbersome judicial process. If last-minute claims satisfy the standards for equitable judicial relief, courts must grant the appropriate relief. But there is nothing unseemly about consigning unreasonably late appeals to a different forum. The claims will at least get a hearing, which is more than they are entitled to receive under remedial principles of equity.

\section{IV.}

The Supreme Court thus correctly ruled that Judge Patel's injunction against Harris' execution was an abuse of discretion. The Court's subsequent conduct, however, leaves much to be desired.

After the Supreme Court issued its April 21 per curiam opinion vacating the two Ninth Circuit stays of execution, Judge Harry Pregerson of the Ninth Circuit issued yet another stay while Harris was strapped into his seat in the gas chamber. The Supreme Court vacated this stay and issued the following order: "No further stays of Robert Alton Harris' execution shall be entered by the federal courts except upon order of this Court." ${ }^{\text {"4 }}$ Professors Caminker and Chemerinsky argue at length that the Court had no authority to issue this order. ${ }^{75}$ We agree.

If the Court's prohibition of any furthur injunctions had been confined to claims directly related to the Eighth Amendment issues that were the actual subjects of the vacated stay orders, one could argue that the Court was, in effect, merely retaining and protecting its jurisdiction over the claims. But the Court's order sweeps far more broadly. It forbids the issuance of any injunction by any federal court based on any claims without prior approval of the Supreme Court. It goes beyond even forbidding Harris to file further applications for stays and purports to control by mandamus all federal courts in cases which have not yet been brought. We cannot imagine where the Court could possibly derive authority to issue such an order. Professors Caminker and Chemerinsky canvas the available sources and find them wanting, and we endorse their conclusion.

Even more fundamentally, as Professors Caminker and Chemerinsky suggest in passing. ${ }^{76}$ such a broad order is probably unconstitutional. ${ }^{77}$ The requirement that the Supreme Court authorize the issuance of any injunctions

74. Vasquez v. Harris, 112 S. Ct. at 1713, 1714 (1992) (No. 5).

75. Caminker \& Chemerinsky, supra note 5, at 246-52.

76. Id. at 252 n.139.

77. We are grateful to Larry Marshall for alerting us to the significance of this point. 
against Harris' execution effectively places original jurisdiction over such claims in the Supreme Court. The Constitution provides for original Supreme Court jurisdiction only in "all Cases affecting Ambassadors, other public Ministers and Consuls, and those in which a State shall be a Party ...."78 Venerable authority holds that this original jurisdiction cannot be expanded by statute ${ }^{79}$ and a fortiori it cannot be expanded by judicial fiat.

The most charitable interpretation of the Court's sweeping order is that the Court did not really intend it to have legal effect, but was simply expressing a willingness to vacate any further injunctions on review. The Court certainly has the power to make such a statement, although one may question the propriety of issuing a press release in the guise of a legal order. The Court may even pre-print orders saying, "stay of Harris' execution vacated or denied," held ready to be issued whenever a stay or stay application comes before the Court. But the orders would still have to be issued, one at a time, in individual "cases" or "controversies" properly before the Court. ${ }^{80}$ An inferior court faced with a new claim by Harris would not have been legally bound by the Court's order. $^{81}$

\section{V.}

Judge Reinhardt closes his Essay by calling on those of us in the academy to consider "perhaps the most important issue to arise out of the disastrous Harris proceeding: what are the limits of the Supreme Court's authority over lower federal courts?"82 We agree with the Judge that the most vital lessons to be drawn from the Harris episode concern the proper relationship between the Supreme Court and the inferior federal courts. Moreover, as we noted at the outset, this issue gains urgency from the recent flurry of high-profile emergency appeals to the Supreme Court from inferior court decisions on equitable relief: not only the Harris case, but also the controversies over Haitian refugees $^{83}$ and the French abortion pill. ${ }^{84}$ An understanding of the nature of the federal judicial hierarchy may thus help the Supreme Court perform its delicate task of reviewing the exercise of equitable discretion, as the structural constitu-

78. U.S. CONST. art. III, $\S 2$, cl. 2.

79. Marbury v. Madison, 5 U.S. (1 Cranch) $137,173-80$ (1803).

80. The same is obviously true with respect to Court orders concerning executive department officials.

81. Given the limited resources available to the Supreme Court, which can only hear perhaps 150 cases per year on the merits, the case or controversy requirement has the practical effect of enhancing the power of inferior courts relative to the Supreme Court. Our casting of the Younger doctrine in purely remedial rather than jurisdictional terms enhances the significance of this limit on the Supreme Court's power.

82. Reinhardt, supra note 4 , at 223.

83. See supra note 1.

84. See supra note 2. These latter two cases, of course, involved federal rather than state law. The principles of judicial hierarchy that we discuss in this section, however, apply to any Supreme Court review of equitable action by inferior courts. 
tional values implicit in Article III are every bit as relevant to courts of equity as the structural values of federalism and separation of powers.

In a recent Article, one of us compared the constitutional grants of power to the federal executive and judicial departments ${ }^{85}$ and indicated that the constitutional text creates a unitary, hierarchical executive but a plural judiciary. ${ }^{86}$ In practice, this means that, whereas the Constitution mandates that the President shall exercise or control all of the executive power, the judicial power is plurally possessed by the judges of the Supreme and inferior federal courts. These different formal structures of the executive and judicial departments have different functional consequences. The command and control structure of the unitary executive hierarchy encourages energy and accountability ${ }^{87}$ while the plurality of the tenured judicial department fosters the desired judicial traits of deliberation, debate, and independence. ${ }^{88}$

But, notwithstanding this vital difference between the executive and judicial departments, the Article III judiciary also displays important elements of internal hierarchy, even if it is more fragmented than the executive department. Article III, Section 1 vests the judicial power in "one supreme Court, and in such inferior Courts as the Congress may from time to time ordain and establish." ${ }^{39}$ Several conclusions flow from this language concerning the extent and form of the judicial hierarchy created by the Constitution. ${ }^{90}$

First, as a recent student note has pointed out, the use of the words "supreme" and "inferior" plainly suggest a hierarchical relationship." This suggestion is bolstered by the usage of these same words in other parts of the Constitution. For example, the use of the word "supreme" in the Supremacy Clause $^{92}$ and the use of the word "inferior" to describe subordinate officers of the United States ${ }^{93}$ support giving those words their natural meanings in Article III. This construction also finds support in the felicitous language of

85. The word "departments" was used deliberately rather than the more common, but incorrect, term "branches." Calabresi \& Rhodes, supra note 39, at 1156 n.6.

86. See id.

87. See THE FEDERALIST No. 70, at 423 (Alexander Hamilton) (Clinton Rossiter ed., 1961); TERRY EASTLAND, ENERGY IN THE EXECUTIVE: THE CASE FOR THE STRONG PRESIDENCY (1992).

88. The Framers obviously believed that the survival of their pluralist constitutional order would benefit from some concentration of power in the executive subject to the check of judicial review.

89. U.S. CoNsT. art. III, § 1 (emphasis added).

90. We have profited greatly from a superb article by Professor David Engdahl. David E. Engdahl, What's in a Name? The Constitutionality of Multiple "Supreme" Courts, 66 IND. L.J. 457 (1991). We disagree with many of Professor Engdahl's conclusions, but his article is consistently thoughtful and provocative.

91. William S. Dodge, Note, Congressional Control of Supreme Court Appellate Jurisdiction: Why the Original Jurisdiction Clause Suggests an "Essential Role," 100 YALE L.J. 1013, 1020-21 (1991).

92. U.S. CONST. art. VI, $\$ 2$ ("This Constitution, and the Laws of the United States which shall be made in Pursuance thereof; and all Treaties made, or which shall be made, under the Authority of the United States, shall be the supreme Law of the Land. . . ."); see Engdahl, supra note 90, at 462 n.20.

93. U.S. CoNST. art. I, § 2, cl. 2 ("[T] he Congress may by Law vest the Appointment of such inferior Officers, as they think proper, in the President alone, in the Courts of Law, or in the Heads of Departments."). 
Article I, Section 8, Clause 9, which gives Congress the power to "constitute Tribunals inferior to the supreme Court." ${ }^{\text {,94 }}$

Second, as noted above, the vesting clause of Article III vests the judicial power in both the Supreme Court and the inferior courts, whereas Article II vests the executive power only in the President, who must delegate that power (perhaps implicitly) to any other officials who would exercise it. While this might suggest that the Supreme and the inferior courts are therefore fully co-equal, a closer look at Article III negates that conclusion. Article III, Section 1 vests the judicial power in the Supreme Court and in such inferior courts as the Congress chooses to create. The use of the word "and" rather than "or" is significant. It suggests that all of the judicial power described in Article III, Section 2 must be vested in the Supreme Court whether or not Congress chooses to create inferior federal courts. Had the Framers instead used the word "or," the argument for full parity of all Article III courts, Supreme and inferior, would be easier to maintain. 95

Third, Article III, Section 1 indicates that there is to be only one Supreme Court, suggesting in the view of some that it would be unconstitutional for that Court to sit in panels. ${ }^{96}$ The debates in the Constitutional Convention make clear that this language replaced a proposal that called for "one or more supreme tribunals" and was adopted on the very same day that the Convention opted for a unitary rather than a plural executive. ${ }^{97}$ Again, the suggestion of hierarchy is very powerful.

Other constitutional provisions also describe a hierarchical relationship between the supreme and inferior federal courts. For example, Article III itself gives the Supreme Court a constitutionally protected original jurisdiction over certain politically sensitive cases ${ }^{98}$ but gives no guaranteed jurisdiction to the inferior courts, which Congress has no obligation to create. Article III also confers on the Supreme Court all of its appellate jurisdiction, subject only to the making of congressional "Exceptions" and "Regulations." "99 Thus, whereas inferior federal courts would be totally disempowered from acting in the absence of federal jurisdictional statutes, the Supreme Court in such event

94. Id. at art. I, \& 8, cl. 9 (emphasis added); but see Engdahl, supra note 90, at 475 n.95.

95. Professor Akhil Amar has pointed out the many respects in which inferior judges enjoy constitutional parity with Supreme Court justices, especially in federal question cases excepted from Supreme Court review. But from the beginning, Professor Amar has acknowledged that inferior judges are not on a par with the justices of the Supreme Court in all respects. See Akhil Reed Amar, Marbury, Section 13, and the Original Jurisdiction of the Supreme Court, 56 U. CHI. L. REV. 443, 477 (1989); Akhil Reed Amar, A NeoFederalist View of Article III; Separating the Two Tiers of Federal Jurisdiction, 65 B.U. L. REV. 205,221 n.60, 231 n.88, 254 (1985) [hereinafter Amar, Two Tiers].

96. See FELIX FRANKFURTER \& JAMES LANDIS, THE BUSINESS OF THE SUPREME COURT $17 \mathrm{n} .124$, 81-82 (1928); Joseph Grinnell, Proposed Amendments to the Constitution: A Reply to Former Justice Roberts, 35 A.B.A. J. 648, 649 (1949); see generally Engdahl, supra note 90, at 462 \& nn.21-22.

97. See Engdahl, supra note 90 , at 464-65.

98. See U.S. CoNST. art. III, $\S 2$, cl. 2; see Dodge, supra note 91, at 1019-20.

99. U.S. CoNST. art. III, $\S 2$, cl. 2. 
would have a much broader appellate jurisdiction than it does today. ${ }^{100}$ Finally, the special status of the Supreme Court is reflected in the decision to designate the Chief Justice as the officer who will preside over the Senate in any impeachment trial of the President of the United States, ${ }^{101}$ and in the specific mention of "Judges of the supreme Court"102 in the appointments clause of Article II. ${ }^{103}$

Two hundred years of evolution and practice have, if anything, made the federal judiciary more hierarchical today than it was in 1789. Circuit riding has been abolished, the statutes governing the Supreme Court's appellate jurisdiction have made progressively fewer exceptions from the constitutional grant, and the Court has been given almost total discretion to set its docket. The net result is that comparative legal scholars routinely contrast our pyramidal court system with the divided multiple judicial hierarchies of the civil law world. ${ }^{104}$

Years of historical practice suggest that some degree of judicial hierarchy is critically necessary, because the tenured judges of the inferior federal courts

100. See Durousseau v. United States, 10 U.S. (6 Cranch) 307, 314 (1810) (stating that an affirmative congressional grant of appellate jurisdiction to the Supreme Court "has been understood to imply a negative on the exercise of such appellate power as is not comprehended within it").

101. U.S. CONST. art. I, $\$ 3$, cl. 6.

102. U.S. CONST. art. II, $\$ 2$, cl. 2.

103. It is tempting to conclude, as some have done, see Dodge, supra note 91 , at 1019 , that the Appointments Clause reinforces the Article III hierarchy by mandating Senate confirmation of Supreme Court judges but not judges of the inferior courts. This, however, misconstrues the Appointments Clause. The clause provides that the President

shall nominate, and by and with the Advice and Consent of the Senate, shall appoint Ambassadors, other public Ministers and Consuls, Judges of the supreme Court, and all other Officers of the United States, whose Appointments are not herein otherwise provided for, and which shall be established by Law; but the Congress may by Law vest the Appointment of such inferior Officers, as they think proper, in the President alone, in the Courts of Law, or in the Heads of Departments.

The enumeration of "Ambassadors, other public Ministers and Consuls, [and] Judges of the supreme Court" describes persons who must be appointed in conformity with the appointments clause-that is, it describes persons who are, by definition, "Officers of the United States-but it does not establish that none of these persons are "inferior Officers" who can be appointed without Senate confirmation. The point is clear upon careful reading of the text; the clause contemplates a distinction between principal officers (who must be appointed with Senate confirmation) and inferior officers, but it does not indicate which officers are principal and which are inferior. It is surely not the case, for example, that all "public Ministers and Consuls" are principal officers who must have Senate confirmation; on that understanding, virtually the entire staff of the State Department would be principal officers. Furthermore, the "Heads of Departments," who are permissible recipients of the appointment power for inferior officers, are surely the paradigm examples of principal officers, yet they are not mentioned in the initial enumeration. Thus, if Supreme Court justices require Senate confirmation, it is not because of their specific mention in the Appointments Clause, but because their position and duties establish them as principal officers. Similarly, the fact that inferior judges are not mentioned in the initial enumeration does not mean that they do not require Senate confirmation if their position and duties indicate that they are principal officers. Indeed, the fact that the "Courts of Law," including the inferior courts, are permissible recipients of the appointment power, along with only the President and the Heads of Departments, strongly suggests that all members of the "Courts of Law" are principal officers who must receive Senate confirmation. We are deeply indebted to Lee S. Liberman, Associate Counsel to the President of the United States, for bringing this argument to our attention. Ms. Liberman's construction of the appointments clause does not necessarily represent the views of the United States government.

104. MARY ANN Glendon, ET AL., COMPARATIVE LEGAL TRADIMONS: TEXT, MATERIAL, AND CASES 108 (1985); JOHN HENRY MERRMMAN, THE CIVIL LAW TRADITION 85-89 (2d ed. 1985). 
are not as independent as the Justices of the Supreme Court. Inferior federal judges sit in states whose Senators often played a major role in their selection, and they commonly have strong ties to powerful political interests in their home states. In addition, it is possible that some of them may even desire promotion, either to a court of appeals or to the Supreme Court, which may also decrease their independence. Accordingly, whether one considers constitutional text, structure, or history, the argument for a full parity of federal judges fails. The federal judiciary is hierarchical and must be so if it is to perform its constitutional role.

Nonetheless, the judicial hierarchy differs in several important respects from the command and control Article II hierarchy over which the President presides. First, because the inferior federal courts share the judicial power with the Supreme Court, when inferior courts have jurisdiction over a case they have total power of decision unless and until they are reversed by the Supreme Court, which usually entails oral argument, briefing, and the writing of opinions. In contrast the Vesting Clause of Article II does not require the President to share the executive power with anyone else; the President accordingly has very broad latitude to issue directions and orders to subordinates. Moreover, the President has considerable power over the salary and promotion prospects of executive department officials.

Second, the tenured judges of the inferior courts do not owe their appointment or continuance in office to the Justices. The inferior courts are thus much more independent of the Supreme Court than even officers of independent agencies are of the President, who generally at least controls their appointment.

Third, the somewhat delphic language of the Exceptions Clause gives Congress power to reduce the appellate jurisdiction of the Supreme Court to some degree in favor of the inferior federal courts (and the state courts). Whether this power is construed to be plenary, limited to preserving an essential role for the Supreme Court, or confined only to allow Congress to pass "housekeeping" measures that reduce the need for travel to Washington, ${ }^{105}$ the clause plainly diminishes the extent to which the Supreme Court is hierarchically dominant over the inferior courts. ${ }^{106}$

105. See Engdahl, supra note 90, at 497-99. See generally CHEMERINSKY, supra note 16, at 151-64 (discussing the various theories of the exceptions power).

106. Nonetheless, the Exceptions Clause does not permit Congress to free the inferior federal courts or the state courts from their obligation to follow Supreme Court precedent in all cases, whether or not Congress has left the Supreme Court jurisdiction to review their judgments. This is a vital theoretical limit on congressional power to disrupt the Article III hierarchy even under the widest conception of the Exceptions Clause. But see Amar, Two Tiers, supra note 95, at $258 \mathrm{n} .178$; Engdahl, supra note 90, at 509.

One of us has elsewhere questioned the use of precedent in federal constitutional and statutory adjudication. See Gary Lawson, Territorial Governments and the Limits of Formalism, 78 CAL. L. REV. $853,870 \mathrm{n} .91$ (1990). Those doubts, however, extend only to the use of precedent by courts at the same level of the federal judicial hierarchy as the court that issued the precedent or by coordinate governmental institutions. The hierarchical structure of Article III dictates that inferior courts faithfully apply the precedents of superior courts, just as the hierarchical structure of Article II requires executive officials to follow presidential precedents. In other words, while Professor Lawson (though not Professor Calabresi) 
Fourth, the fact that inferior federal judges sit in the states and are beholden to their Senators adds to their independence of the Supreme Court and introduces an important element of federalism into the national court system. No comparable federal element exists within the national executive, although there may be some members of that department who are more beholden to Congress than to the President.

Finally, inferior court independence of the Supreme Court is augmented by many other practical aspects of our appellate review system, including: 1) the fact that the Supreme Court can review only 100 to 150 of the more than 70,000 cases that the federal courts decide in any given year; 2) the great discretion that trial courts may have in structuring trials or finding facts; and 3) the fact that after the Supreme Court has decided a case, there will often remain some vital role for the inferior courts to play before the legal matter will come to an end. Accordingly, the Article III judicial hierarchy does not resemble the command and control "military" hierarchy contemplated by the text of Article II. Rather, it is a hierarchy that allows issues to bubble up to the Supreme Court slowly, after much time has passed and passion has dissipated, and perhaps with the hope that many of the most contentious issues will disappear along the way. This system gives the Supreme Court the last word, but only over a single case or controversy and only after much deliberation and delay.

How, then, do these concerns apply to the Supreme Court's exercise of its equitable discretion in the Harris case or the other recent appeals in equity that it has heard? It seems to us that the structural nature of the Article III judicial hierarchy could profitably be kept in mind by all federal courts when they exercise their equitable discretion. Just as we argued that equitable discretion should be informed by structural concerns of federalism and separation of powers, we also believe that it should be informed by structural concerns that grow out of the nature of the Article III judicial hierarchy. These two types of structural values are related in that they further pluralism by dividing power enough to preserve freedom, while concentrating power enough so that the government can function when consensus exists. In practice, all of this means that the judges of the Ninth Circuit must remember that they are in some real sense "inferior" to the Supreme Court. At the same time, the Justices of the Supreme Court must remember that they cannot (and should not want to) order the inferior courts around as if they were the Joint Chiefs of Staff. Circuit judges must remember that the Supreme Court not only has the power to reverse their judgments and orders but also to bind them precedentially, and

believes that precedent in the federal system is problematic when applied horizontally, he agrees that precedent is a proper and important part of the judicial system when applied vertically. 
that it simply will not do to act on the premise that, as one federal judge is rumored to have said, "Well, they can't reverse 'em all."107

Conversely, something is surely wrong when the Supreme Court finds itself repeatedly issuing orders on stay applications by divided votes of 7-2 or 5-4, as has happened this year. While there may be rare occasions when this is warranted, the Court would do well to remember here its general policies against interlocutory review, the granting of certiorari before judgment, and summary dispositions. Many of these policies suggest the wisdom of deferring review, of avoiding the micromanagement of particular cases, as well as the importance of full briefing, oral argument, and disciplined opinion writing.

The Supreme Court's intervention in the Haitian refugees case, which involved the federal government's recent policy of intercepting boatloads of refugees on the high seas and returning them to Haiti, is an example of improper micromanagement. In a 2-1 decision, ${ }^{108}$ the Second Circuit Court of Appeals held that the government's policy violated $\$ 243(\mathrm{~h})(1)$ of the Immigration and Nationality Act. ${ }^{109}$ The Supreme Court issued a stay of the Second Circuit's judgment pending a petition for certiorari. The case presents important questions of statutory and treaty interpretation and of the proper application of principles of collateral estoppel, and the decision arguably conflicts with a prior decision of the Eleventh Circuit. ${ }^{110}$ It is clearly a prime candidate for plenary review by the Supreme Court.

It is another matter, however, whether the Court should have issued a stay. A party seeking such an unusual exercise of the Court's equitable powers must show "(1) a likelihood of irreparable harm if the judgment below is not stayed; (2) a reasonable probability that certiorari will be granted; (3) a significant possibility that the judgment below will be reversed; and (4) that the balance of the equities tilts clearly in its favor." ${ }^{\text {"111 }}$ It is hard to see how the government satisfied this heavy burden. The government's position on the merits may well prevail in the end, but the issues are complicated enough to give one pause in the absence of full briefing and argument. More importantly, this is not a

107. District judges, by the same token, should be reluctant to issue nationwide as opposed to districtwide injunctions. See, e.g., Massachusetts v. Bowen, 679 F. Supp. 137, 147-48 (D. Mass. 1988) (issuing a nationwide injunction against enforcement of the so-called "gag-rule" against abortion counseling in federally funded clinics), aff'd, 899 F.2d 53 (Ist. Cir. 1990), vacated and remanded sub nom. Sullivan v. Massachusetts, 111 S. Ct. 2252 (1991). They should instead let issues bubble up through the national court system where possible. Of course, that will not always be possible. A stay of the government's actions with respect to the Haitian refugees, for example, cannot help but have nationwide effect.

I08. Haitian Ctrs. Council v. McNary, No. 92-6144, 1992 U.S. App. LEXIS 17372 ( 2d. Cir. July 29, 1992).

109. 8 U.S.C. $\S 1253(\mathrm{~h})(1)(1992)$ ("The Attomey General shall not deport or retum any alien ... to a country if the Attomey General determines that such alien's life or freedom would be threatened in such country on account of race, religion, nationality, membership in a particular social group, or political opinion.").

110. Haitian Refugee Ctr. v. Baker, 953 F.2d 1498 (11th Cir.), cert. denied, 112 S. Ct. 1245 (1992).

111. McNary v. Haitian Ctrs. Council, No. A-82, 1992 U.S. LEXIS 4766 (Aug. 1, 1992) (Blackmun, J., dissenting). 
case in which the equities point strongly in the moving party's direction. If the government is right but is not permitted to return (assumedly) illegal aliens to Haiti, that is indeed a serious harm to American sovereignty and interests, and courts should give due weight and deference to the executive department's assertion of such interests. ${ }^{112}$ But if the government is wrong, aliens who are returned to Haiti under the government's (assumedly) illegal policy face harm at least as serious, possibly including death. ${ }^{113}$ We believe that the equities in favor of the government would have to be much stronger and clearer to warrant preliminary intervention by a Supreme Court sitting at the top of a large national judicial hierarchy. ${ }^{114}$

In Harris, however, these considerations of hierarchy point in the opposite direction. The equitable case against Harris, who was now working on what was effectively his tenth petition for post-conviction relief over a period of thirteen years, was overwhelming. The flurry of stays from the Ninth Circuit at least gave the appearance of obstructionism-even if, as Judge Reinhardt explains at length, the reality was very different. ${ }^{115}$ From the Supreme Court's perspective, maintenance of order within the federal judicial hierarchy required equitable intervention. ${ }^{116}$

A hierarchical judicial system that handles tens of thousands of cases and provides for appellate review requires a relationship of trust among the superior and inferior courts. In an ideal world, discretionary decisions, such as decisions to grant or deny equitable relief, are left primarily to the courts closest to the action. The system collapses if the higher courts will not, or cannot responsibly, defer to inferior courts on discretionary judgment calls. The real question raised by the Harris case may thus be the extent to which the Supreme Court is becoming, and should become, a court of error, devoted primarily to reigning in rogue inferior court decisions in particular cases. The question is not trivi$\mathrm{al},{ }^{117}$ and the answer is not obvious.

112. Such cases obviously present separation of powers concerns, which we have repeatedly argued ought to inform decisions of federal courts with respect to equitable relief.

113. Moreover, unlike Harris, any returned Haitians who face death will do so without nine post-conviction trips up and down the American judicial system over more than a decade passing judgment on their legal claims.

114. Conversely, the Court's refusal to vacate the Second Circuit's stay of an injunction in the French abortion pill controversy, Benten v. Kessler, 112 S. Ct. 2929 (1992), displayed appropriate reluctance to intervene in the early stages of a case. It is interesting to note that Justices Blackmun and Stevens, who quite properly opposed the stay in Haitian Centers Council, urged intervention in Benten. See id. at 2930 (Blackmun, J., dissenting); id. (Stevens, J., dissenting).

115. The Court, of course, must act on the basis of the evidence available to it and the inferences that can rationally be drawn from that evidence. Perhaps the Court was influenced by its past conflicts with the Ninth Circuit; in 1984, the Supreme Court reviewed 28 Ninth Circuit decisions and reversed 27 of them. See Bishop, When Appeals Court Becomes a Big Issue in Death-Row Cases, N.Y. TIMEs, May 22, 1992, at B18.

116. This does not, of course, excuse or explain the Court's sweeping order of April 21, 1992, forbidding any future injunctions against Harris' execution without leave of the Court.

117. See Anthony D'Amato, Aspects of Deconstruction: Refuting Indeterminacy with One Bold Thought, 85 Nw. U. L. REV. 113, 118 (1990) (suggesting that Supreme Court should pay more attention to doing justice in individual cases than to pronouncing broad policies). 
